\title{
Technical efficiency of smallholder honey farmers in Jimma zone, Ethiopia
}

\author{
Hailemariam Legesse $^{1}$, Yadeta Bekele ${ }^{1}$, Mulubrihan Bayissa ${ }^{1}$, Tsega Lemma ${ }^{2}$ \\ ${ }^{1}$ Jimma University \\ P.O. Box 307, Cluj-Napoca, Federal Democratic Republic of Ethiopia \\ ${ }^{2}$ Stellenbosch University \\ Private Bag X1, Matieland, 7602, Stellenbosch, Republic of South Africa
}

\begin{abstract}
This study analyzes technical efficiency and determinants of the efficiency of honey production in the Gomma and Gera districts of the Jimma zone. The data were obtained from 194 randomly selected honey-producing smallholder farmers. A Cobb - Douglas stochastic frontier production analysis with the inefficiency effect model was used to estimate technical efficiency and identify the determinants of efficiency variations among honey farmers. The study showed that several hives and supplementary feeds positively and significantly influenced honey yield. This shows that there is room to increase honey productivity from the current level if farmers can efficiently use these input variables. The result further showed that there were differences in technical efficiency among honey producers in the study area. The discrepancy ratio, $\gamma$, which measures the relative deviation of output from the frontier level due to inefficiency, was about $84 \%$. This implies that about $84 \%$ of the variation in honey output among the farmers was attributed to technical inefficiency effects. The estimated mean level of technical efficiency of honey producers was about $74 \%$. This reveals that there is a possibility to increase the level of honey output by about $26 \%$ through exploiting the existing local practices and technical knowledge of the relatively efficient farmers. The education level of the farmer, landholding, income, extension contact, and training were found to determine technical efficiency significantly. Therefore, the concerned sector should focus on the above variables to enhance the technical efficiency of honey producers in the study area.
\end{abstract}

Keywords: stochastic frontier, technical efficiency, smallholder farmers, Ethiopia

\section{Introduction}

Agriculture is still dominating the Ethiopian economy sharing about $43 \%$ of the GDP, $80 \%$ of employment, and $90 \%$ of export earnings (Demese et al., 2010). Smallholder farmers account for more than $85 \%$ of the rural population who directly engaged in agricultural production.

Ethiopia is blessed with numerous types of wild honeybees. This situation made Ethiopia be one of the countries on the continent which own huge honey production potential. Despite this fact, the country still could not harvest this real potential for the required amount due to several reasons. Southwestern part of 
the country, particularly Jimma zone, is known for its considerable potential for honey production. There is a growing trend of honey production in the zone, where many households are engaged in honey production for income and consumption. Despite the substantial potential, the majority of the rural households in the study area inclined to traditional methods of beekeeping. This implies that the honey sector in the area is not developed to the expected level. Thus, the beekeeper farmers are not economically benefited out of it to the extent it ought to be due to several reasons (Abiyu Zewde, 2011).

The country has the highest bee density, and it is the leading honey producer and the largest beeswax exporters in Africa. Despite this considerable production potential and marketing opportunity, the share of the sub-sector in the GDP of the country has never been proportionate. According to B. Tessega (2009), honey production has been low, leading to low utilization of hive products locally and quite low export earnings.

The real potential for honey production in Ethiopia made the country to have a comparative advantage for honey and beeswax production. By increasing productivity, the country can exploit this competitive advantage to develop a significant export trade. This will also improve the incomes of beekeeping farmers and other participants, including large and small-scale commercial apiculture (MoFED, 2010). However, the apiculture sector is far from realizing its potential. According to the report from the Ministry of Agriculture (2013), less than 10\% of the honey and wax potential have been tapped.

Currently, most of the honey produced in Ethiopia is produced by smallholder farmers who practice by traditional beehives make up to about $96 \%$ of the total quantity of honey productions (Miklyaev et al., 2013).

According to K. Chala et al., (2013), the trends of the honey yield of the past five years (2005 to 2009) in the Gomma district were increasing from 13,002 to $31,650.25 \mathrm{~kg}$. Despite this positive trend, the majority of the farmers practice traditional ways of honey production, as well as the inefficient utilization of resources. This indicates there is still unexploited potential in the district. This might be the reason why farmers are collecting less output and low income from honey production.

Measuring the technical efficiency of agricultural production determines the efficiency level of households in their farming activities (Ilembo, Kuzilwa, 2014). One of the reasons for the poor development of the sector could be because of the low level of technical efficiency of beekeeping farmers in the study area. Analyzing the technical efficiency of honey production in different production systems will enable us to determine whether smallholder farmers make use of all the available potentials in their agricultural activities or not and identify which production system is technically efficient.

Although farmers in Gomma and Gera districts of Jimma zone are relatively good in practicing modern honey production (Ephrem, 2013), the majority of them still rely on the traditional honey production system. Several factors are believed to attempt the use of modern production system in the study area. Several studies conducted in the past have characterized honey production and marketing systems, value-added honey products, factors that affect development of beekeeping in Ethiopia (Zewde, 2011; Chala et al., 2013; Yetimwork et al., 2015; Tadesse, 
2011; Kebede, Tadesse, 2014; Kumsa, Takele, 2014; Tessega, 2009; Metages, 2014). However, almost no studies have been conducted on technical efficiency and determinants of honey production. Moreover, there is only one study that systematically investigated the extent of the technical efficiency of the sub-sector (Kaleb, Berhanu, 2015). However, as to the knowledge of the researchers, there is no previous study on the production efficiency and determinants of honey production. Thus, the current study will estimate and compare the status of the technical efficiency of honey production and its determinants in different production systems in the study area.

\section{Research methodology. Description of the research area}

The study was conducted in the Gomma and Gera districts of Jimma zone, where farmers are relatively better in practicing the modern honey production system. Gomma district is located in the mid-altitude sub-humid zone of the southwestern part of Ethiopia. The district is located at $390 \mathrm{~km}$ from Addis Ababa. The topography of the district ranges from gently sloping to hilly lands with ridges and valleys in between. The total surface area of the district is $96.4 \mathrm{~km}$. The rainy season extends from May to September, with the highest rainfall usually recorded in August. The mean annual rainfall varies between 1400 and 1650 millimeters with average maximum and minimum temperatures of 29.9 and $13.4^{\circ} \mathrm{C}$, respectively, and the altitude is 1400 to 2270 m.a.s.1.

Gera district is bordered on the south by the Gojeb River, which separates it from the Southern Nations, Nationalities and Peoples Region, on the northwest by Sigma, on the north by Setema, on the northeast by Gomma, and on the east by Seka Chekorsa. The 2007 national census reported a total population for this woreda of 112,395, of whom 56,488 were men and 55,907 was women; 4,746 or $4.22 \%$ of its population were urban dwellers. The majority of the inhabitants were Muslim, with $85.64 \%$ of the population reporting they observed this belief, while $11.9 \%$ of the population said they practiced Ethiopian Orthodox Christianity, and $2.36 \%$ were Protestant.

The altitude of this woreda ranges from 1390 to 2980 meters above sea level. A survey of the land in this woreda shows that $26.5 \%$ is arable or cultivable (23.4\% was under annual crops), $7.0 \%$ pasture, $56.6 \%$ forest, and the remaining $9.9 \%$ are considered degraded, built-up or otherwise unusable. There is a vast area of the two districts covered with vegetation in the region, including the study area. Spices, coffee, corn, and teff are important cash crops of the districts. Moreover, the districts are known in their honey production potential. This is partly due to the relatively better technology uptake of the farmers (Ephrem, 2013).

\section{Data type and source}

Both qualitative and quantitative data were used. Data on the level of production inputs (such as number of hives, labour used, extension service, land, and other supplementary feeds), farmer-specific (inefficiency) factors and other sociodemographic characteristics of respondents that are hypothesized to influence the honey production system such as age, educational level, marital status, princi- 
pal occupation, membership of social groups and years of experience in beekeeping was collected from primary and secondary sources. The primary data were collected from beekeeper farmers, district agriculture experts, development agents, and district administrators. Secondary data were gathered from district agriculture and rural development office and other relevant offices, books, journals, and the internet.

\section{Method of data collection}

In order to get relevant data related to the research questions, household surveys, focus group discussions, critical informant interview, and personal observations were used.

\section{Sampling technique}

Depending on the nature of the model to be used, and the goal of the study, multiple stage technique of sampling were used to select representative samples. First, Gomma and Gera districts were selected, taking in to account their honey production potential and good practice of modern honey production system. Secondly, the top three kebeles from each district based on their production potential were selected purposively. Third, beekeeping farmers in these kebeles were selected after stratified as traditional, transitional, modern, and mixed honey producers. Finally, a simple random sampling method was employed to select a total of 194 respondents from the sixth kebeles of the two districts based on proportional probability sampling procedure using the following formula (S.B. Green, 1991) as cited in (Wilson Van Voorhis, Morgan, 2007):

$$
n \geq 50+8 * x
$$

where $n=$ sample size, $x=$ number of independent variables (18 variables in this case).

\section{Data analysis and model specification}

The collected data was coded, edited, and entered into SPSS 23 computer software due to its suitability for data entry. Then, after proper edition, it was exported to statistical software, STATA, which is relatively good for data analysis. Thus, the recent version of STATA 13 software was used for data analysis. Then the data were analyzed through descriptive statistics and econometric models.

\section{Stochastic Frontier Analysis (SFA)}

The two most commonly used approaches to measuring the efficiency of a producer are Stochastic Frontier Analysis (SFA) and Data Envelopment Analysis (DEA). The later, DEA, is a non-parametric approach that involves mathematical programming and assumes that all deviations from the frontier output are due to technical inefficiency. However, in this study, the SFA approach was used because it was a parametric approach that uses econometric methods, and it considers both an inefficiency component and a random error. Moreover, the SFA approach is usually preferred to estimate efficiencies of production systems because of the very nature of agricultural productions depends on climatic conditions and 
is affected by measurement errors that attribute for statistical noise in data sets and stochastic frontier models allows decomposition of error terms between statistical noises and inefficiencies measure that enables statistical tests on the validity of model specification (Fekadu, 2004; Chen, 2007).

Thus, Stochastic Frontier Analysis (SFA) was used to address the first and second specific objectives which analyze the status of the technical efficiency of honey production and its determinants. The stochastic production function used in this study, which includes both the deterministic part and random shocks, can be specified as:

$$
y_{i} f\left(x_{i}, \beta\right) * \exp \left(v_{i}\right) * T E_{i},
$$

where $y_{i}$ is the scalar output of producer $i, x_{i}$ is a vector of $M$ inputs used by producer $i, \beta$ is a vector of technology parameters to be estimated, and $T E_{i}$ is the output-oriented technical efficiency of producer $i$ which provides a measure of the shortfall of observed output from maximum feasible output, $f\left(x_{i}, \beta\right)$ a deterministic part common to all produces, $\exp \{v i\}$ producer-specific random shocks and $\left[f\left(x_{i}, \beta\right) * \exp \left(v_{i}\right)\right]$ is a stochastic production frontier.

Cobb - Douglas and translog models are the most widely used specification of the production function in recent literature (Greene, 2008). In this particular study, the linear form of the Cobb - Douglas production function was used.

The log-linear form of the Cobb - Douglas functional form is mathematically formulated as follows:

$$
\operatorname{Ln} Y=\beta_{0}+\beta_{1} \operatorname{Ln} X_{1}+\beta_{2} \operatorname{Ln} X_{2}+\beta_{3} \operatorname{Ln} X_{3}+\beta_{4} \operatorname{Ln} X_{4}+\beta_{5} \operatorname{Ln} X_{5}+V i-U i,
$$

where $\mathrm{Y}$ - production of honey per period production $(\mathrm{kg} / \mathrm{pp}) ; X_{1}, X_{2}, X_{3}$, and $X_{4}-$ inputs used (number of beehive, land allocated for honey production, supplemental feed, and labor used) by producer $1,2,3,4 \ldots ; \beta_{0}-$ constant; $\beta_{1}-\beta_{5}-$ parameter input variables are not fixed suspected; $\mathrm{Ln}=$ natural $\operatorname{logarithm} e=2.718 ; \mathrm{Vi}-$ mistakes made due to a random; $U i$ - effect of technical efficiency appears.

It expected that different production systems demand different kinds and amounts of inputs. In this study, the most important inputs in honey production are classified into four categories, namely: number of beehive, land allocated for honey production, labor used, and supplemental feed.

The technical inefficiency effects model developed by T. Coelli and G.E. Battese (1998) were adopted for this study. Below is the parameter value distribution of technical inefficiency function which was enabled us to calculate the effect of technical inefficiency:

$$
\mu_{i}=\delta_{0}+\delta_{1} Z_{1}+\delta_{2} Z_{2}+\delta_{3} Z_{3}+\delta_{4} Z_{4}+\delta_{5} Z_{5},
$$

where $\mu_{i}=$ technical inefficiency effects; $Z_{1}, Z_{2}, Z_{3}, Z_{4}$, and $Z_{5}$ are exogenous variable; $\delta_{0}=$ constant; $\delta_{1}-\delta_{5}-$ parameter variables inefficiency.

The hypothesized determinants of technical inefficiency in honey production include sex of the household head, age of the household head, education status of the household head, household size, income, honey production system practice by the farmer, total number of hives and household access to institutions such as market, credit and extension services. The following Table 1 summarizes the hypothesized determinants of beekeepers' technical efficiency in the study area. 
Hypothesized production variables and determinants of honey farmers' technical efficiency level

\begin{tabular}{clc}
\hline Variable ID & \multicolumn{1}{c}{ Description } & Expected sign \\
\hline AGE & Age of household head, continuous (years) & $+\mathrm{ve}$ \\
GENDER & Gender of household head, dummy $(1=$ male, $0=$ female) & $-\mathrm{ve}$ \\
EDUC & The educational level of HH head, continuous (years of schooling) & $+\mathrm{ve}$ \\
FZ & Family size, continuous variable in numbers & $-\mathrm{ve}$ \\
LNDBK & Land for beekeeping (continuous) & $+\mathrm{ve}$ \\
DIST & Distance to the market place, continuous in minutes of walk on foot & $-\mathrm{ve}$ \\
LABOR & Adult equivalent (continuous) & $+\mathrm{ve}$ \\
HIVES & Number of hives owned, continuous variable (in numbers) & $+\mathrm{ve}$ \\
EXPER & Beekeeping experience, continuous (years) & $+\mathrm{ve}$ \\
INCOME & The annual income of the household, continuous (ETB) & $+\mathrm{ve}$ \\
CR & Access to credit service, dummy (1= yes, $0=$ no) & $+\mathrm{ve}$ \\
EXT & Extension contact, continuous (numbers of visits) & $+\mathrm{ve}$ \\
INFO & Access to market information, dummy $(1=$ yes, $0=$ no) & $+\mathrm{ve}$ \\
TRAIN & Access to training, dummy (1= yes, $0=$ no) & $+\mathrm{ve}$ \\
SPLMT & Value of supplement purchased & $+\mathrm{ve}$ \\
\hline
\end{tabular}

Source: authors' hypothesis based on previous literature (2018).

\section{Results and discussions}

\section{Descriptive statistics}

The following table presents summary statistics of production variables (the physical inputs used in the production of honey output used for analysis in the stochastic production frontier model.

\section{Descriptive statistics}

\begin{tabular}{lcccc}
\hline \multicolumn{1}{c}{ Variable } & Mean & Std. dev. & Min & Max \\
\hline $\begin{array}{l}\text { Output variable } \\
\text { Input variables: }\end{array}$ & 134.85 & 154.44 & 10 & 750 \\
LNDBK & 0.20 & & & \\
LABOR & 12.45 & 0.24 & 0.01 & 1 \\
HIVES & 33.29 & 10.83 & 1 & 40 \\
SPLMT & 610.24 & 32.77 & 5 & 191 \\
\hline
\end{tabular}

Source: authors' computation (2018).

The result indicates that, on average, a household produced $134.85 \mathrm{~kg}$ of honey per season. The average land area allocated to honey production was approximately $0.2 \mathrm{ha}$, that ranged from 0.01 to 1 ha with a standard deviation of 0.24 ha. The mean land size indicates that honey producers in the study area are using forest, which also confirms that one of the characteristics of honey production in Ethiopia. The mean level of labour (both family and hired) used by honey producers was found to be 12.45 person-days, which was obtained by aggregating labour used for all honey production activities.

The minimum and maximum level of labour (person-day) used are 1 and 40 person-days respectively; 10.83 were labour used difference among the farmers. The average number of hives owned by the farmers was 33.29 with 32.76 quantity of difference among the farmers. Regarding the value of supplement used farmers in the study area commonly using bee forage and during the dry season thus used sugar and bean flours as feed supplements to bees, which values on average around 610.24. 


\section{Inefficiency variables}

The following table presents the summary statistics of both continuous and dummy efficiency variables that were included in the honey production technical efficiency model.

Table 3

Descriptive summary statistics of technical inefficiency variables

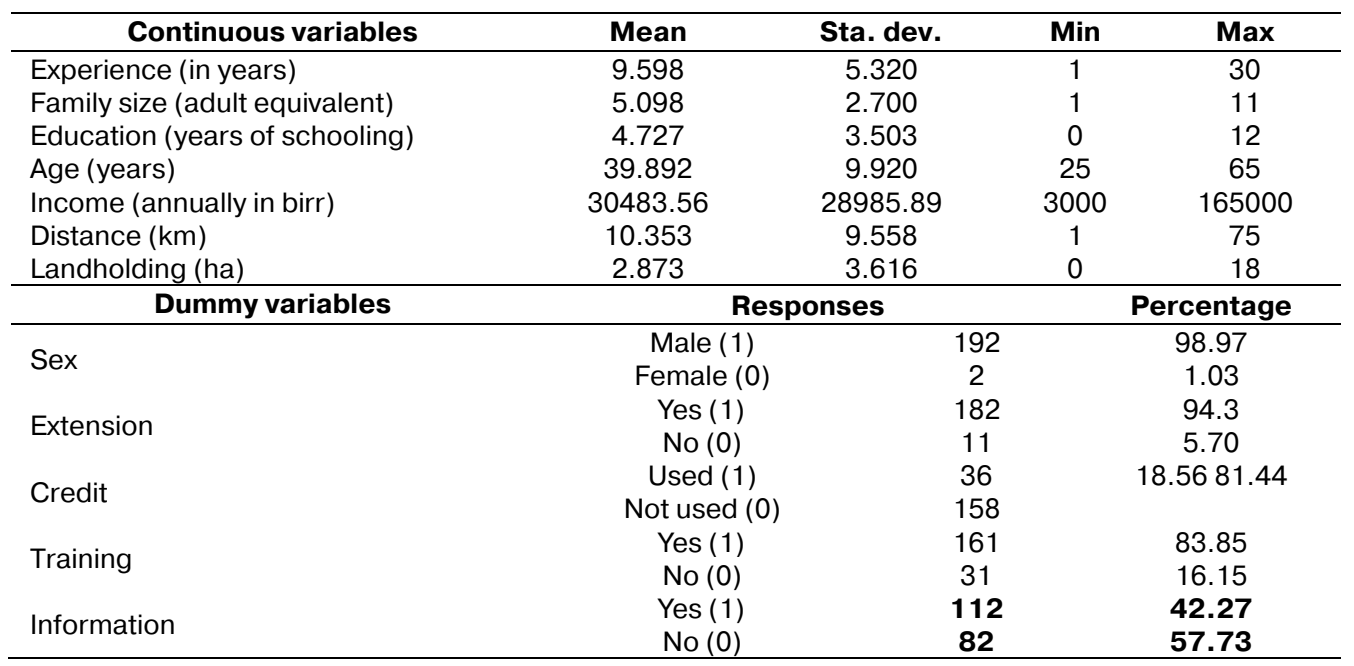

Source: authors' computation (2018).

The results in Table 3 indicate during the specified honey production season, farmers in the study area, on average, had 9.6 years of beekeeping experience with a minimum, maximum, and standard deviation of 1,30 , and 5.3 years of experience respectively. The average household family size was approximately 5.1, with a maximum of 11 and a minimum of one adult equivalent persons. Besides, on average, farmers in the study area achieved five years of schooling, and the average age of the respondents was approximately 40 years, with a maximum of 65 and a minimum of 25. The table also depicts that the average amount of income the household got from honey production in the season was approximately $30,483.56$ birr with a standard deviation of 28985.89. On average, the landholdings of the household in the production season were 2.9 ha with a standard deviation of 3.62 ha with minimum and maximum holding of 0 and 18 ha respectively. The result shows that, on average, the market was $10.35309 \mathrm{~km}$ far from the honey production site. The survey result shows that a female-headed a maleheaded $98.97 \%$ of the respondents' farmers and $1.03 \%$ of the respondents. The average extension contact, credit service, training, and information service a farmer received was reported to be $94.3,18.56,83.85$, and $42.27 \%$ the remaining did not have these services during the production season.

\section{Hypotheses testing}

One attractive feature of the SPF method is that it is possible to test various hypotheses using the maximum likelihood test ratio. Therefore, before discussing parameter estimates of production frontier function and the inefficiency effects, it is 
advisable to run several hypotheses tests in order to choose an appropriate model for further analysis and interpretation.

Tests of hypothesis for the parameters of the frontier model are conducted using the generalized likelihood ratio statistics, $\lambda$.

Generalized likelihood-ratio test of hypotheses for parameters of SPF

\begin{tabular}{ccccc}
\hline Null hypothesis & df & $\lambda$ & Critical value (99\%) & Decision \\
\hline$H_{0}: \beta i j=0$ & 6 & 13.56 & 16.81 & Accept $H_{0}$ \\
$H_{0}: \gamma=0$ & 1 & 12.1 & 3.84 & Reject $H_{0}$ \\
$H_{0}: \mu=\delta_{1}=\delta_{2}=\delta_{3}=\ldots \delta_{15}=0$ & 12 & 140.84 & 26.23 & Reject $H_{0}$ \\
\hline
\end{tabular}

Source: authors' computation (2018).

The hypotheses that whether there is inefficiency in the production of honey was tested against the null hypothesis, $H_{0}: \gamma=0$, where the parameter, $\sigma^{2}=\sigma^{2} /\left(\sigma^{2}+\sigma_{v}{ }^{2}\right)$, such that there is no inefficiency in the production of honey. If the null hypothesis is correct, the SPF is equivalent to the normal response function. Hence in this case, if there is an output difference among farmers given equal inputs, the difference is purely due to random errors that are outside of the control of the farmer. This hypothesis can be tested using the generalized likelihood ratio test based on the log-likelihood function under Ordinary Least Squares estimation and final maximum likelihood estimation. The generalized likelihood ratio statistics, $\lambda=12.1$, presented is found to be higher than the critical value of 3.84 . Hence we can reject at a $1 \%$ level of significance the null hypothesis that the average response function is an adequate representation of the data. Consequently, the null hypothesis that honey-producing farmers in the area are fully efficient is rejected. Hence there is considerable inefficiency among farmers in the production of honey in the study area.

Table 5

Parameter estimates of the SPF model

\begin{tabular}{lccc}
\hline \multicolumn{1}{c}{ Variables } & Coefficients & Std. err. & Elasticity \\
\hline Inland & $0.169^{\star \star \star}$ & 0.049 & 0.169 \\
Inlabor & 0.057 & 0.052 & 0.057 \\
Intotalnhvs & $0.635^{\star \star \star}$ & 0.083 & 0.635 \\
InSup & $0.44^{\star \star \star}$ & 0.054 & 0.44 \\
Intercept & $3.554^{\star \star \star}$ & 0.376 & \\
sigma2 & $1.554^{\star \star \star}$ & 0.230 & \\
lambda & $2.298^{\star \star \star}$ & 0.158 & $\mathbf{0 . 8 6 1}$ \\
$\gamma$ & 0.8408 & & \\
\hline
\end{tabular}

Note: significant at ${ }^{* \star *}(1 \%),{ }^{\star \star}(5 \%)$ and ${ }^{*}(10 \%)$ total elasticity 1.301 .

Source: authors' computation (2018).

The next hypothesis is that the null hypothesis that the explanatory variables associated with the technical inefficiency effects model are all zero $H_{0}: \mu=\delta_{1}=\delta_{2}=$ $=\delta_{3}=\ldots \delta_{15}=0$. To test this hypothesis likewise, $\lambda$ was calculated using the value of the log-likelihood function under the stochastic frontier model (a model without explanatory variables of inefficiency effects, $H_{0}$ ) and the full frontier model (a model with variables that are presumed to determine inefficiency of each farmer, $\left.H_{1}\right)$. The calculated value of $\lambda=140.84$ is higher than the critical value of 26.23. Thus the null hypothesis that variables in the inefficiency effects model are 
simultaneously equal to zero is rejected at a $1 \%$ level of significance. Therefore, the explanatory variables associated with the inefficiency effects model are simultaneously different from zero. Hence these variables simultaneously explain the difference in inefficiency among farmers.

A single-stage maximum likelihood estimation procedure was employed to estimate the parameters of both stochastic frontier production function and inefficiency effect model simultaneously.

As the table above indicates, the estimated coefficients for land allocated for honey production, total numbers of hives, and supplement feed were all positive, which confirms that there is a positive relationship between these inputs and the output. Besides, the positive coefficients of these variable inputs imply that an increase in quantities of these inputs would increase output. Though, on average, as we increase land allocated to honey production, amount of total numbers of improved hives, and the amount of supplementary feed for the production of honey by $1 \%$ each, we can increase the level of honey output by $0.169,0.635$ and $0.44 \%$ respectively. In another way, the elasticity of production which is the percentage change in output as a ratio of a percentage change in input was used to calculate the rate of return to scale which is a measure of a firm/farm's success in producing maximum output from a set of input (Farrell, 1957). The returns to scale were used to measure the proportionate increase in output resulting from a given proportionate increase in all inputs. The returns to scale can be either of increasing, decreasing or constant, if the sum of the estimated partial elasticity's is more significant than, less than or equal to one, respectively. As it is indicated in the table above, the summation of the partial elasticity's ( $\sum \varepsilon P=R T S$ ) of all input is 1.301. This implies that an increase in these inputs by one percent may lead to an increase in production by $1.301 \%$. As the study was initiated to measure how efficiently honey producer farmers in the study area utilized and organized their inputs and identify determinants contributing to inefficiency of honey producers in the study area, there was a need to analyze the technical efficiency of honey production and determine factors contributing to inefficient in honey production. Therefore, productive efficiency analysis in honey production was estimated based on the performances relative to the observed or estimated average honey output.

It should be noted that all the parameter coefficients of the production variables were obtained by the value of their physical quantity. In this study, it was found that except labour, all the other variables found to be significant. This might indicate that they could have a significant role in honey production in the study area. Though total number hives, supplementary feed, and land allocated for honey production contribute to high to honey production, it also indicated that it was underutilized by farmers in the study area.

\section{Estimation of farm-level technical efficiency}

The mean level of technical efficiency of honey-producing farmers was about $74 \%$, with the minimum and maximum efficiency level of about 25 and $90 \%$ respectively. This shows that there is a wide disparity among honey producer farmers in their level of technical efficiency, which may, in turn, indicate that there exists room for improving the current level of honey production by enhancing the level of farmers' technical efficiency. The mean level of technical efficiency 
further tells us that the level of honey output of the sample respondents can be increased on average by about $26 \%$ if appropriate measures are taken to improve the level of efficiency of honey growing farmers. In other words, there is a possibility to increase the yield of honey by about $28 \%$ using the resources at their disposal in an efficient manner without introducing any other improved (external) inputs and practices.

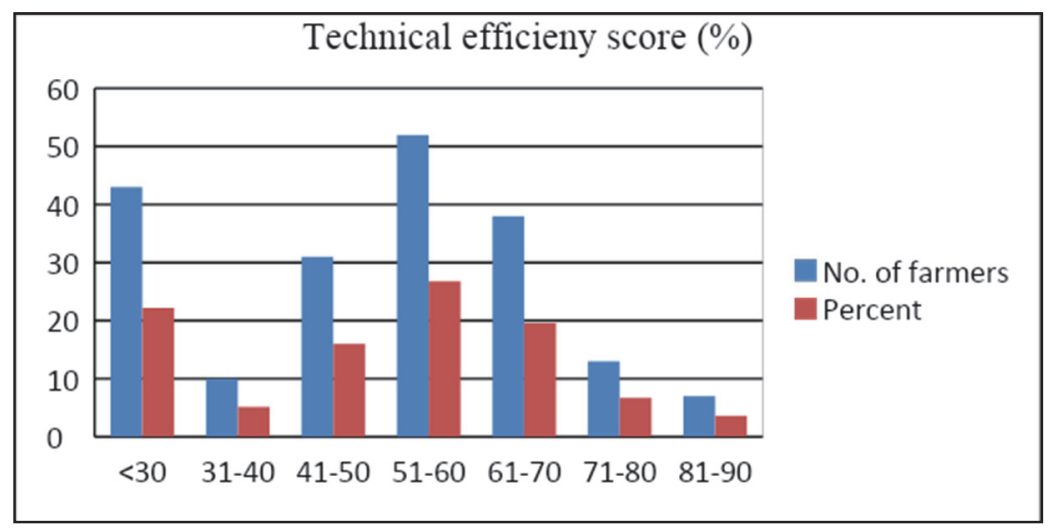

Figure. Percentage distribution of farmers by technical efficiency scores

Source: own elaboration.

Moreover, there is a considerable difference in technical efficiency among farmers that ranged from a minimum of 25 to a maximum of 90 . A frequency distribution presented in the bar graph in range shows that about $70 \%$ of the sample farmers were operating below the overall mean level of technical efficiency. At the same time, about $3.61 \%$ of the farmers were operating at the technical efficiency level of more than $80 \%$.

\section{Determinants of inefficiency}

The coefficients of honey production inefficiency variables included in the model were estimated using the estimated level of $T E$ as the variable. Since the dependent variable of the inefficiency function represents the model of inefficiency, a negative sign on an estimated parameter implies that the associated variable had a positive effect on efficiency, and a positive sign indicates that the reverse is true. The table below presents the sources/determinants of technical inefficiency in honey production.

In this study, education measured in years of formal schooling, as expected, the sign of education was negative, implying that less-educated farmers are not technically efficient than those that have relatively more education. This could be because; educated farmers can use information from various sources and can apply the new information and technologies on their farm that would increase outputs of honey. This result was in line with the findings of most studies reviewed, including those of (Shiferaw, Gebremedhin, 2016).

As can be seen in Table 6, the perceived landholding had a significant and positive impact on technical efficiencies, as expected. This implies that land is an essential factor in influencing the level of efficiency in the production of honey. The result is consistent with (Fekadu, 2004). 
Table 6

Maximum likelihood estimates of the factors determining technical inefficiency

\begin{tabular}{lcc}
\hline \multicolumn{1}{c}{ Variables } & Coefficients & Std. err. \\
\hline Age & 0.0436 & 0.0286 \\
Sex & 0.7942 & 0.8841 \\
Education & $0.2007^{\star \star \star}$ & 0.0635 \\
Family size & 0.0913 & 0.1087 \\
Landholding & $0.1155^{\star \star}$ & 0.0510 \\
Experience & -0.0137 & 0.0401 \\
Information & -0.0104 & 0.2328 \\
Income & $0.0001^{\star}$ & 0.0001 \\
Distance to the nearest market & 0.0099 & 0.0171 \\
Credit source & -0.5570 & 0.4452 \\
Extension contact & $0.8440^{\star}$ & 0.4996 \\
Training & $1.7024^{\star \star \star}$ & 0.5116 \\
Cons & $4.4394^{\star \star \star}$ & 1.4748 \\
\hline
\end{tabular}

Note: significant at ${ }^{\star \star *}(1 \%),{ }^{\star \star}(5 \%)$ and ${ }^{\star}(10 \%)$.

Source: authors' computation (2018).

Income is an essential variable in explaining the variation of technical efficiency among farmers. The positive and significant impact of income in this study implies that if the farmer's income increases, it enables them to make timely purchases of inputs. In other words, farmers who had enough income were more technically efficient than farmers who had no income source. This result is consistent with (Shiferaw, Gebremedhin, 2016).

The result also shows that extension determined the inefficiency level of farmers negatively and significantly. This is consistent with the prior expectation that those farmers that had relatively more extended extension contact will score a higher efficiency level. The improvement in the production system of honey in the study area was the significant focuses of extension. The integration of income and input supply with the extension system as a package approach was supposed to have induced the use of improved technologies in the production of honey. In the study area, the contact those farmers have with extension workers play a significant role in improving the level of technical efficiency. The result obtained reveals that, given the existing technology at hand, bringing farmers under extension contact and rendering them the necessary advisory service in every aspect can help farmers increase their level of technical efficiency in honey production.

As more beekeeping training they receive, the more technically efficient the beekeeper becomes. This finding is in line with that of A. Olohungbebe and P. Daniel (2015), who noted that adequate training on the rudiments of beekeeping determined the improvement of resource use efficiency for honey production. The training and extension services the beekeepers receive tends to strengthen beekeepers' technical know-how, thereby improving their beekeeping performance. Exposure to training and extension services allows beekeepers to acquire new insights into beekeeping.

\section{Conclusion}

Productivity can be improved in two ways either by introducing new agricultural production technologies or improving the technical efficiency levels of farmers which is the possible strategies to increase the productivity of the agricultural sector in the country. Technical efficiency has remained an essential subject 
of empirical investigation, particularly in developing economies where the majority of the farmers are resource-poor. Alternatively, productivity growth may attribute to either technological progress or efficiency improvement. Improving the technical efficiency of the farmer plays a significant role in increasing productivity, given the current state of technology. This paper analyzed the technical efficiency and factors that explain the variation in efficiency among honey-producing farmers in the Gomma and Gera district of Oromia National Regional State. Relevant data related to honey production were collected for the 2016/17 production season from 195 sample farmers. The Cobb - Douglas stochastic production frontier model with inefficiency effects was used to analyze the level of technical efficiency of the farmers concerning honey production and the causes of technical inefficiency differentials among the farmers.

The hypothesis that technical efficiency effects are absent, given the specification of Cobb - Douglas stochastic frontier production function, was rejected based on the results of the econometric model. This shows that the technical inefficiency exists in the sample farmers considered. Hence, the normal response function that all farmers are fully technically efficient is not supported by the result obtained from the statistical analysis of the data.

The estimated stochastic production frontier model indicated that by land allocated for honey production, the total number of hives and supplementary feeds is significant determinants of honey output. The positive coefficient of these parameters indicates that increased use of these inputs will increase the production level to a greater extent. Hence, given that these inputs are used to their maximum potential, the introduction and dissemination of these inputs will increase the production level of honey in the study area. Also, the estimated result of the Cobb Douglas production frontier indicated that a significant proportion of the variation in the stochastic frontier production function is due to technical inefficiency. This implies that the presence of a chance for improvement of farmers' productivity through better technical efficiency. The mean technical efficiency level of $74 \%$ indicates that production can be increased by $26 \%$. Hence, if inputs are used to their maximum potential, there will be considerable gain from improvements in technical efficiency.

Moreover, there is wide variability in the technical efficiency level of farmers, and only a few farmers attained efficiency levels of more than $80 \%$ for honey production in the study area. This inefficiency, however, can be improved if factors that determine the technical efficiency level of farmers in the production of honey among farmers in the study area are identified. The estimated model, together with the inefficiency, showed that the educational level of the household head, landholding of the household, and income of the farmers, frequency of extension contact, and training are significant determinants of the technical inefficiency level of the farmers in honey production.

In general, the SPF model showed that production could be improved by increasing the use of inputs. There is considerable room to improve the efficiency of farmers in honey production. The implication is that there will be a considerable gain in production level if the introduction and distribution of agricultural technologies are joined with improving the current level of efficiency. 


\section{Recommendations}

Those farmers that are educated are relatively more technically efficient than uneducated ones in the study area. This is because educated farmers have access to information and better communication media that helps them to use modern agricultural honey production technologies efficiently. Education is fundamental in improving the technical efficiency of farmers. Therefore, the regional government should facilitate farmers' access to education that could be implemented through the expansion of farmers' training center or expansion of formal and nonformal education in the area.

Landholding of beekeeping affected the technical efficiency of farmers positively. Therefore, the regional government and the concerned sectors must create awareness on the land allotted for beekeeping in honey production.

It was shown that the income of the farmers had a positive correlation with technical efficiency since if the farmer's income increases, it enables them to make timely purchases of inputs. So the regional government gives attention to diversifying the source of income for the farmers in the area.

The result of the study reveals that farmers who have extension contact were more efficient than farmers without extension contact. So farmers with no extension contact can improve their performance level at least to be as technically efficient as those who have contact with extension workers. Hence, given the existing technology at hand, bringing farmers under extension contact and rendering them the necessary advisory service can help farmers increase their level of technical efficiency of honey production.

Training also influences technical efficiency. So training on honey production has to be created via the establishment of sufficient training institutions and strengthening of the available development agents to assist farmers in terms of training to improve productivity, honey.

\section{References}

Abdulai, Abdul-Malik, \& Abubakari Mohammed. (2012). Technical efficiency of beekeeping farmers in Tolon-Kumbungu district of Northern region of Ghana. Journal of Development and Agricultural Economics, 4(11), 304-310. doi: 10.5897/JDAE12.074.

Abiyu, Zewdie. (2011, June). An Assessment of Factors That Affect Development Of Beekeeping In Rural Areas: The Case Of Hurumu District, Ilubabor Zone, Oromia Regional State, Ethiopia (Thesis Submitted to the School Of Graduate Studies Of Addis Ababa University In partial fulfillment of the requirements for the degree of Master of Arts in rural livelihoods and development). Addis Ababa, Ethiopia.

Amanuel, Tadesse, (2011). Value chain and cost benefit analysis of honey production and its implication on household food security: a comparative analysis of certified and conventional honey in GinboWereda, southern Ethiopia (A thesis submitted to the food security studies program of the college of development studies in partial fulfillment of the requirements for the degree of Master of Science in food security studies). Addis Ababa, Ethiopia.

ATA (Agricultural Transformation Agency). (2014). Annual report transforming agriculture in Ethiopia. Addis Ababa, Ethiopia.

Chala, K., Taye, T., Kebede, D., \& Tadele, T. (2012, March). Opportunities and challenges of honey production in Gomma district of Jimma zone, South-West Ethiopia. Journal of 
Agricultural Extension and Rural Development, 4(4), 85-91. Retrieved from http:// academicjournals.org/JAERD

Chala, K., Taye, T., Kebede, D., \& Tadele, T. (2013, April). Assessment of Honey Production and Marketing System in Gomma District, South Western Ethiopia. Greener Journal of Business and Management Studies, 3(3), 99-107.

Chen, C.-F. (2007). Applying the stochastic frontier approach to measure hotel managerial efficiency in Taiwan. Tourism Management, 28(3), 696-702.

Coelli, T., Rao, D.S.P., \& Battese, G.E. (1998). Introduction to efficiency and production analysis. Kluwer Academic Publisher, USA.

CSA (Central Statistics Authority). (2012). Agricultural sample survey 2011/2012 on livestock and livestock characteristics. Addis Ababa, Ethiopia.

Ephrem, T. (2013, April). Zonal Diagnosis and Intervention Plan Report for Jimma Zone.

Farrell, M. (1957). The Measurement of Productive Efficiency. Journal of the Royal Statistical Society. Series A (General), 120(3), 253. doi: 10.2307/2343100.

Fekadu, G. (2004). Analysis of technical efficiency of wheat production: A study in Machakelworeda (An M.Sc. Thesis presented to the School of Graduate Studies of Haramaya University). Ethiopia.

Greene, W. (2008). The Econometric Approach to Efficiency Analysis. In H.O. Fried, C.A. Knox Lovell \& S.S. Schmidt (Eds), The Measurement of Productive Efficiency and Productivity Growth (chapter 2, pp. 92-250). Oxford University Press, Oxford.

Ilembo B., \& Kuzilwa, J. (2014, July). Technical Efficiency Analysis of Tobacco Production in Tanzania. Interdisciplinary Journal of Contemporary Research in Business, 6(3), 246-265.

Kebede, H., \& Tadesse, G. (2014). Survey on honey production system, challenges and Opportunities in selected areas of Hadya Zone, Ethiopia. Journal of Agricultural Biotechnology and Sustainable Development, 6(6), 60-66. doi: 10.5897/JABSD2014.0232.

Kuboja, N.M., Isinika, A.C., \& Kilima, F.T.M. (2017). Determinants of economic efficiency among small-scale beekeepers in Tabora and Katavi regions, Tanzania: a stochastic profit frontier approach: Development Studies Research.

Miklyaev, M., Jenkins G.P., \& Barichello R.R. (2013). Honey Production in Ethiopia: A CostBenefit Analysis of Modern versus Traditional Beekeeping Technologies. JEL: D13, D31, D61, D62.

MoFED. (2010). Growth and Transformation Plan (GTP) 2010/11-2014/15. Addis Ababa, Ethiopia.

Olarin de, L.O., Ajao, A.O., \& Okunola, S.O. (2008). Determinants of Technical Efficiency in Bee-Keeping Farms in Oyo State, Nigeria: A Stochastic Production Frontier Approach. Research Journal of Agriculture and Biological Sciences, 4(1), 65-69.

Olohungbebe, A.S., \& Daniel, P.O. (2015). Resource-use Efficiency of Honey Production in Kachia Local Government Area, Kaduna-State, Nigeria. Journal of Agricultural Studies, 4(1), 117-126.

Shiferaw, K., \& Gebremedhin, B. (2015). Technical efficiency of small-scale honey producer in Ethiopia: A Stochastic Frontier Analysis. MPRA Paper No. 69332. Retrieved from https://mpra.ub.uni-muenchen.de/69332/

Shiferaw, K., \& Gebremedhin, B. (2016). Technical efficiency of small-scale honey producers in Ethiopia: A stochastic frontier analysis. LIVES Working Paper 20. Nairobi, Kenya: International Livestock Research Institute (ILRI).

Tessega, B. (2009). Honeybee Production and Marketing Systems, Constraints and opportunities in Burie District of Amhara Region, Ethiopia (A Thesis Submitted to the Department of Animal Science and Technology, School of Graduate Studies Bahirdar University).

Tolera, Kumsa, \& Dejene, Takele. (2014, May).Assessment of the effect of seasonal honeybee management on honey production of Ethiopian honeybee (Apismellifera) in modern beekeeping in Jimma Zone. Research Journal of Agriculture and Environmental Management, 3(5), 246-254. Retrieved from http://www.apexjournal.org 
Wilson Van Voorhis, C.R., \& Morgan, B.L. (2007). Understanding Power and Rules of Thumb for Determining Sample Sizes. Tutorials in Quantitative Methods for Psychology, 3(2), 43-50.

Yetimwork, Gebremeskel, Berhan, Tamir, \& Desalegn, Begna. (2015). Honey bee production trend, potential and constraints in Eastern Zone of Tigray, Ethiopia. Agriculture and Biology Journal of North America, 6(1), 22-29. doi: 10.5251/abjna.2015.6.1.22.29.

\title{
Article history:
}

Received: 08 October 2019

Revised: 23 December 2019

Accepted: 16 January 2020

\section{For citation:}

Legesse, H., Bekele, Y., Bayissa, M., \& Lemma, T. (2020). Technical efficiency of smallholder honey farmers in Jimma zone, Ethiopia. RUDN Journal of Economics, 28(1), 7-22. http://dx.doi.org/10.22363/2313-2329-2020-28-1-7-22

\section{Bio notes:}

Yadeta Bekele, lecturer and researcher, College of Agriculture and Veterinary Medicine, Jimma University. E-mail: yadeta11@gmail.com

Mulubrihan Bayissa, Head of the Department of Agricultural Economics \& Agribusiness Management, Jimma University. E-mail: coaes@haramaya.edu.et

Tsega Lemma, PhD Candidate, Department of Agricultural Economics, Stellenbosch University. E-mail: info@sun.ac.za

Научная статья

\section{Увеличение эффективности фермерских хозяйств в зоне Джиммы, Эфиопия}

\author{
Х. Легессе ${ }^{1}$, Я. Бекеле ${ }^{1}$, М. Баисса ${ }^{1}$, Т. Лемма ${ }^{2}$ \\ ${ }^{1}$ Университет Джиммы \\ Федеративная Демократическая Республика Эфиопия, Клуж-Напока, \\ Почтовый офис, ящик 307 \\ ${ }^{2}$ Стелленбосский университет \\ Южно-Африканская Республика, 7602, Стелленбос, Matieland, Private Bag X1
}

В статье анализируются факторы эффективности фермерских хозяйств по производству меда в районах Гомма и Гера зоны Джиммы. Данные были получены от 194 случайно отобранных фермерских хозяйств, производящих мед. Исследование показало, что увеличение количества ульев и дополнительных кормов положительно влияет на урожайность меда. Дальнейшее изучение выявило различия в технической эффективности среди производителей меда в исследуемой области. В результате было установлено, что около $84 \%$ различий в производстве меда среди фермеров объясняется технической неэффективностью. Средний уровень технической эффективности производителей меда составил около 74 \%. Это показывает, что существует возможность повысить уровень производства меда примерно на 26 \% за счет использования опыта и технических 
знаний более эффективных фермерских хозяйств. Уровень образования фермеров, владение землей, доход, повышение квалификации являлись определяющими факторами повышения технической эффективности.

Ключевые слова: стохастическая граница, техническая эффективность, мелкие фермерские хозяйства, Эфиопия

\section{История статьи:}

Дата поступления в редакцию: 08 октября 2019

Дата проверки: 23 декабря 2019

Дата принятия к печати: 16 января 2020

\section{Для цитирования:}

Legesse H., Bekele Y., Bayissa M., Lemma T. Technical efficiency of smallholder honey farmers in Jimma zone, Ethiopia (Увеличение эффективности фермерских хозяйств в зоне Джиммы, Эфиопия) // Вестник Российского университета дружбы народов. Серия: Экономика. 2020. Т. 28. № 1. С. 7-22. http://dx.doi.org/10.22363/2313-2329-2020$28-1-7-22$

\section{Сведения об авторах:}

Бекеле Ядета, исследователь, лектор Колледжа сельского хозяйства и ветеринарной медицины, Университет Джиммы. E-mail: yadeta11@gmail.com

Баисса Мулубрихан, заведующий кафедрой экономики сельского хозяйства и управления агробизнесом, Университет Джиммы. E-mail: coaes@haramaya.edu.et

Лемма Тсега, кандидат наук, кафедра экономики сельского хозяйства, Стелленбосский университет. E-mail: info@sun.ac.za 